\title{
ע Varhainen puuttuminen nuorten rikoksiin ja hyvinvointiin liittyviin ongelmiin: kyselytutkimus monialaista yhteistyötä tekeville ammattilaisille
}

Tutkimuksen tarkoituksena oli kuvata poliisin, sosiaalitoimen, terveystoimen ja nuorisotoimen monialaista yhteistyötä toteuttavien ammattilaisten käsityksiä varhaisesta puuttumisesta nuorten rikolliseen käyttäytymiseen ja hyvinvointiin liittyviin ongelmiin sekä arvioita toiminnan kehittämisestä. Tutkimusaineisto kerättiin sähköisellä kyselyllä keväällä 2018 valtakunnallisen ankkuritoiminnan ammattilaisilta $(n=52)$ ja heidän esimiehiltään $(n=28)$. Aineisto analysoitiïn kuvailevilla tilastollisilla menetelmillä. Tulosten mukaan monialaista yhteistyötä toteutettiin yleisimmin tilanteissa, jossa nuori oli tehnyt rikoksen (86\%) oli epäiltynä rikoksesta (84\%) tai käyttänyt huumeita $(81 \%)$ tai muita päihteitä $(79 \%)$. Vastaajista yli puolet $(55 \%)$ oli tunnistanut asiakkaillaan väkivaltaista radikalisoitumista. Vastaajat kokivat, että ankkuritoiminnalla pystytään estämään nuorten rikoskäyttäytymistä ( $89 \%$ ), lisäämään yhteiskunnan sisäistä turvallisuutta $(81 \%)$ sekä edistämään terveyttä ja hyvinvointia $(70 \%)$. Toiminnan vahvuuksia olivat henkilöstön sitoutuminen $(79 \%)$ ja yhteistyö tïmin sekä sidosryhmien kanssa. Tämä, kuten myös monialaisen toiminnan johtaminen, kuvattiin edellyttävän vielä jatkokehittämistä. Lisäksi monialaisen yhteistyön mahdollisuuksia parantaisi se, että lainsäädäntö esimerkiksi tiedonvaihdon osalta olisi täsmällisempää. Tulevaisuudessa tarvitaan lisää tietoa siitä, miten monialaista toimintaa voidaan johtaa monialaisesti. Lisäksi nuorten yhdenvertainen palveluiden saatavuus tulisi varmistaa yhtenäisellä kansallisella ohjauksella.

ASIASANAT: hyvinvointi, kyselytutkimus, nuoret, varhainen puuttuminen

TANJA MOILANEN, MATTI AIRAKSINEN, MARI KANGASNIEMI

\section{YDINASIAT}

- Nuorten hyvinvoinnin erot ovat lisääntyneet viime vuosikymmeninä ja tarve moniammatillisiin palveluihin poliisin, sosiaali-, terveys- ja nuorisotoimen yhteistyönä nuorten ongelmiin puuttumiseksi on kasvanut.

- Tulokset osoittavat, että kansallisesti on kuitenkin havaittavissa eroja siinä, miten ja millaisia palveluita nuorilla on käytettävissä.

- Lisätutkimustietoa tarvitaan siitä, miten monialaisilla palveluilla voidaan tasa-arvoisesti vastata nuorten tarpeisiin ja miten toimintaa tulisi johtaa.

\section{JOHDANTO}

Suurin osa nuorista voi hyvin. Osalle nuorista on kuitenkin kasautunut moniulotteisia hyvinvointiin liittyviä ongelmia, jotka kohdistuvat esimerkiksi terveyteen $(1,2)$, päihteiden käyttöön $(1,3)$ sekä sosiaaliseen eriarvoisuuteen $(1,4,5)$. Nuorten ongelmien kannalta keskeistä on, että ongelmiin puututaan monialaisesti ja varhaisessa vaiheessa $(6,7)$, jotta ongelmien kumuloituminen ja vaikeutuminen voidaan ehkäistä. Varhaisella tuella ja puuttumisella tarkoitetaan sitä, että nuorten ongelmat havaitaan, tunnistetaan ja ne pyritään tarvittaessa ratkaisemaan mahdollisimman var- 
haisessa vaiheessa (8). Monialaisella yhteistyöllä puolestaan tarkoitetaan sekä eri ammattilaisten että muiden kunnan ja kolmannen sektorin toimijoiden työskentelyä, joka tähtää yhteiseen ja jaettuun tavoitteeseen (9-12). Monialaisen ja varhaisen tuen avulla nuoren yksilöllinen tilanne ja tuen tarve voidaan tunnistaa monipuolisesti ja palvelun tarpeeseen voidaan vastata kattavasti yhdistämällä eri toimialojen ammattilaisten osaaminen $(7,13,14)$.

Suomessa nuorten varhaisen tuen ja puuttumisen palveluita tarjotaan muun muassa ankkuritoiminnassa, joka on eri toimialarajat ylittävää ja siitä vastaa julkinen sektori. Ankkuritoiminnan tarkoituksena on puuttua varhaisessa vaiheessa nuorten hyvinvointiin liittyviin ongelmiin ja rikoskäyttäytymiseen (15). Lisäksi tehtävänä on tunnistaa ja puuttua mahdolliseen väkivaltaiseen radikalisoitumiseen ja ekstremismiin $(15,16)$. Ankkuritoiminta on valtakunnallisesti koordinoitua ja sitä toteutetaan tiimeissä, johon kuuluvat poliisi, sosiaalityöntekijä, sairaanhoitaja ja nuorisotyöntekijä. Tiimi tapaa nuoren mahdollisimman varhaisessa vaiheessa. Tällä pyritään estämään ongelmien kumuloituminen. Ankkuritoiminnassa toteutetaan lisäksi yhteistyötä muiden kunnan sekä kolmannen sektorin toimijoiden kanssa. Suomessa ankkuritoimintaa tai siihen rinnastettavaa toimintamallia on toteutettu 2000luvun alusta lähtien, ja vuonna 2012 asetettiin tavoite, jonka mukaisesti toimintamalli otetaan käyttöön koko maassa (17). Vuonna 2020 toimintaa oli noin 60 kunnan alueella (18). Aikaisempaa tutkimustietoa toiminnan valtakunnallisesta toteuttamisesta ja sen kehittämiskohteista ei kuitenkaan ole saatavilla.

Sekä kansallisesti että kansainvälisesti monialaisen yhteistyön hyödyt nuorten varhaiseen tukeen ja puuttumiseen on tunnistettu (7,19-22). Monialaisilla varhaisen tuen palveluilla voidaan tarjota kokonaisvaltaista ja koordinoitua tukea ja kohdentaa se nuoren yksilöllisten tarpeiden mukaisesti $(6,7,12,21,23,24)$. Monialaisen yhteistyön haasteena on, että jo eri tehtävien vuoksi ammattilaisilla on erilaiset tietoperustat, koulutukset ja työmenetelmät. Esimerkiksi ankkuritoiminnassa poliisien perustehtävä kohdistuu turvallisuuden edistämiseen ja rikosten estämiseen, terveydenhuollon ammattilaisten terveyden edistämiseen ja sosiaali- ja nuorisotoimen edustajilla hyvinvoinnin edistämiseen $(15,25)$. Monialai- nen työskentely edellyttää, että sekä ammattilaiset että esimiehet ovat sitoutuneet yhteisen työtavoitteen saavuttamiseen ja heillä on yhteinen käsitys toiminnan lähtökohdista, työmenetelmistä ja päätöksenteosta (12).

Kansallisesti monialaista yhteistyötä on tarkasteltu jo 1990-luvun yhteistoiminnan näkökulmasta (esim. 22), ja viime vuosina tarkastelu on kohdistunut monialaiseen yhteistyöhön muun muassa lastensuojelussa $(22,27)$, perhetyössä (2830), terveydenhuollossa (31), työllistymisen tukemisessa $(32,33)$ ja kotouttamisessa (34). Näissä monialaisuus on muodostunut erityisesti sosiaali- ja terveydenhuollon ja koulutoimen yhteistyöstä. Kansainvälisesti monialaista yhteistyötä nuorten rikoksiin varhaisessa puuttumisessa on tyypillisesti tarkasteltu poliisin ja sosiaalitoimen välisenä toimintana (20). Tutkittua tietoa on kuitenkin edelleen niukasti siitä, miten nuorten varhainen tukeminen voidaan toteuttaa monialaisessa yhteistyössä, johon osallistuu useiden eri toimialojen ammattilaisia. Tieto on tarpeen, jotta voitaisiin tunnistaa tekijöitä, joilla nuorten kokonaisvaltainen tukeminen ja varhaisen puuttumisen palvelut voidaan järjestää ja johtaa monialaisesti.

Tämän tutkimuksen tarkoituksena on kuvata monialaista yhteistyötä toteuttavien ammattilaisten käsityksiä varhaisesta puuttumisesta nuorten rikolliseen käyttäytymiseen ja hyvinvointiin liittyviin ongelmiin sekä heidän arvioitaan toiminnan kehittämisestä. Tässä tutkimuksessa monialainen toiminta on rajattu suomalaiseen ankkuritoimintaan, jota toteutetaan poliisin, sosiaalitoimen, terveystoimen ja nuorisotoimen yhteistyönä. Tavoitteena on tuottaa uutta tietoa monialaisten toimintamallien vahvistamiseen ja toiminnan kehittämiseen, jotta palvelut vastaisivat nuorten muuttuviin tarpeisiin. Tutkimuskysymykset ovat:

i. Mitkä ovat monialaisen toiminnan keskeiset tavoitteet ja tehtävät nuorten tukemisessa?

ii. Millaisia käsityksiä ammattilaisilla on monialaisen yhteistyön toteutumisesta ja kehittämistarpeista?

\section{MENETELMÄT}

\section{AINEISTONKERUU}

Tutkimusaineisto kerättiin valtakunnallisesti sähköisellä kyselylomakkeella keväällä 2018. Tutkimuksen kohderyhmänä oli monialaisesti ammat- 
tilaiset nuorten varhaisen puuttumisen palveluista, joita tässä tutkimuksessa edusti ankkuritoimijat poliisista, sosiaalitoimesta, terveystoimesta ja nuorisotoimesta. Tekstissä monialaisissa palveluissa toimivia ammattilaisia kuvataan käsitteellä ankkuritoimijat. Aineistonkeruuta varten laadittiin kyselylomake aiemman kirjallisuuden, lainsäädännön ja toimintaa ohjaavien dokumenttien perusteella. Kyselylomakkeen sisältö ja rakenne arvioitiin asiantuntijapaneelissa, jonka muodosti ankkuritoiminnan kehittämisryhmä, sisältäen edustajia ankkuritoiminnan kannalta keskeisistä kansallisista toimijoista, kuten opetus- ja kulttuuriministeriöstä, sisäministeriöstä, sosiaali- ja terveysministeriöstä, Poliisihallituksesta, Terveyden- ja hyvinvoinninlaitoksesta, Kuntaliitosta sekä Poliisiammattikorkeakoulusta. Lisäksi kyselylomake esitestattiin kahden paikkakunnan ammattilaisilla ja esimiehillä $(\mathrm{n}=14)$, jotka työskentelevät ankkuritoimintamallin mukaisesti. Esitestaukseen osallistui siten poliisin, sosiaali- ja terveystoimen sekä nuorisotoimen ammattilaisia. Testaukseen osallistuvia ammattilaisia pyydettiin arvioimaan lomakkeen kysymysten sisältöä ja ymmärrettävyyttä. Esitestauksen palautteet kerättiin joko puhelin- tai Skype-haastatteluilla. Ohjausryhmältä ja ammattilaisilta saatujen palautteiden perusteella täsmennettiin vastausvaihtoehtoja ja kyselyyn vastaamisen ohjeistusta. Palautteiden perusteella myös tarpeettomiksi tai päällekkäisiksi koetut väittämät poistettiin ja joitakin täydentäviä kysymyksiä lisättiin.

Kyselylomakkeita laadittiin kaksi, ensimmäinen esimiehille (114 kysymystä) ja toinen ammattilaisille (138 kysymystä). Kyselylomakkeet olivat sisällöllisesti samanlaiset, mutta niiden kysymykset oli muotoiltu siten, että asioita tarkasteltiin esimiesten ja ammattilaisten näkökulmista. Lomakkeissa oli monivalintakysymyksiä sekä niitä täydentäviä ja täsmentäviä laadullisia kysymyksiä. Lomakkeen kysymykset kohdistuivat ankkuritoiminnan organisoimiseen ja toteutukseen, johtamiseen ja kehittämiseen sekä moniammatilliseen yhteistyöhön nuorten ja perheiden tukemiseksi. Tässä artikkelissa raportoidaan tutkimuskysymysten mukaiset kyselyn tulokset kohdistuen monialaiseen toimintaan nuorten tukemisessa ja toiminnan kehittämiseen.

Osallistujiksi rekrytoitiin valtakunnallisen ankkuritoiminnan ammattilaiset ja heidän esimiehensä $(\mathrm{N}=196)$. Kohdejoukko eli 112 toimi- jaa ja 84 esimiestä tavoitettiin poliisilaitosten yhteyshenkilöiden avulla. Yhteyshenkilöt välittivät tutkimuksesta sähköisen tiedotteen osallistujille. Vapaaehtoiset osallistujat ilmoittautuivat yhteyshenkilölle, joka välitti tiedon heistä edelleen tutkijoille. Sähköinen tiedote sisälsi internet-linkin kyselyyn vastaamiseen. Tutkimuksen kohdejoukolle järjestettiin videoneuvotteluyhteydellä kaksi saman sisältöistä vuorovaikutuksellista tiedotustilaisuutta. Tiedotustilaisuuksissa tutkijat kertoivat tutkimuksen kulusta ja kyselyn toteuttamisesta. Osallistujilla oli mahdollisuus esittää kysymyksiä tutkimukseen liittyen.

\section{ANALYSOINTI}

Kyselylomakkeen monivalintakysymykset analysoitiin Statistical Package for the Social Sciences version 24 (SPSS) -ohjelmalla. Vastaukset analysoitiin kuvailevilla tilastollisilla menetelmillä, siten, että muuttujille laskettiin frekvenssit ja prosentit. Taustamuuttujien vastauksista ikä ja työkokemus luokiteltiin vuosien mukaisesti. Lisäksi ristiintaulukoitiin ammattilaisten ja esimiesten vastaukset ammattiryhmittäin, kuvaamaan ammattilaisten ja esimiesten erillisiä käsityksiä. Ammattilaisten ja esimiesten käsitysten erojen tarkasteluun käytettiin Mann-Whitney U-testiä. Avointen kysymysten vastaukset olivat yksittäisiä sanoja tai lauseita, jotka perustelivat tai täydensivät monivalintakysymyksiä. Nämä vastaukset yhdisteltiin ja ryhmiteltiin kysymysten alla samanlaisuuksien ja erilaisuuksien perusteella ja niistä poimittiin raporttiin monivalintakysymyksiä täydentäviä esimerkkejä.

\section{TULOKSET}

\section{VASTAAJIEN TAUSTATIEDOT}

Kyselyn kokonaisvastausprosentti oli 41. Vastaajista $(n=80) 52$ oli ankkuritoimintaan osallistuvia ammattilaisia ja 28 esimiehiä. Vastaajien keskiikä oli 54,3 vuotta ja he olivat 29-62-vuotiaita. Vastaajista pääosa oli alle 50-vuotiaita naisia ja esimiehistä valtaosa oli yli 50-vuotiaita miehiä. Kyselyyn vastaajat edustivat poliisia $(42,5 \%)$, sosiaalitoimea $(23,8 \%)$, terveystoimea $(18,8 \%)$ ja nuorisotoimea $(11,3 \%)$. Lisäksi kyselyyn vastasi muita ammattilaisia (3,8 \%) kuten koulutoimen edustajia. Vastaajat olivat maantieteellisesti 28 eri alueelta. (Taulukko 1.) 
Taulukko 1 . Kyselyyn vastaajien taustatiedot.

\begin{tabular}{lcccccc}
\hline & \multicolumn{2}{c}{ Ammattilaiset } & \multicolumn{2}{c}{ Esimiehet } & \multicolumn{2}{c}{ Kaikki } \\
& $\mathbf{n}$ & $\mathbf{\%}$ & $\mathbf{n}$ & $\mathbf{\%}$ & $\mathbf{n}$ & $\mathbf{\%}$ \\
\hline Vastaajat & 52 & 65 & 28 & 35 & 80 & 100 \\
\hline Sukupuoli & 52 & & 27 & & 79 & \\
Nainen & 36 & 69,2 & 12 & 44,4 & 48 & 60,8 \\
Mies & 15 & 28,8 & 15 & 55,6 & 30 & 37,9 \\
Ei halua vastata & 1 & 1,9 & - & - & 1 & 1,3 \\
\hline Vastaajien ikä & 50 & & 28 & & 78 & \\
29-39 & 17 & 34,0 & 2 & 7,1 & 19 & 24,4 \\
40-49 & 23 & 46,0 & 10 & 35,7 & 33 & 42,3 \\
50-59 & 10 & 20,0 & 11 & 39,3 & 21 & 26,9 \\
60- & - & - & 5 & 17,9 & 5 & 6,4 \\
\hline Työkokemus ko. ammatissa & 50 & & 24 & & 74 & \\
0-10 & 20 & 40,0 & 7 & 29,2 & 27 & 36,5 \\
11-20 & 22 & 44,0 & 7 & 29,2 & 29 & 39,2 \\
21-30 & 8 & 16,0 & 10 & 41,6 & 18 & 24,3 \\
\hline Taustaorganisaatio & 52 & & 28 & & 80 & \\
Poliisi & 23 & 44,2 & 11 & 39,3 & 34 & 42,5 \\
Sosiaalitoimi & 14 & 26,9 & 5 & 17,9 & 19 & 23,7 \\
Terveystoimi & 9 & 17,3 & 6 & 21,4 & 15 & 18,7 \\
Nuorisotoimi & 4 & 7,7 & 5 & 17,9 & 9 & 11,3 \\
Muut & 2 & 3,8 & 1 & 3,6 & 3 & 3,8 \\
\hline & & & & & & \\
\hline
\end{tabular}

\section{ANKKURITOIMINNAN KOHTEET JA ASIAKKAIDEN VALINTA}

Vastaajien mukaan ankkuritoiminta heidän alueellaan kohdistui yleisimmin tilanteisiin, joissa nuori oli tehnyt rikoksen $(86,3 \%$ ), häntä epäiltiin rikoksesta $(83,8 \%)$ tai nuori oli käyttäneen huumeita $(81,3 \%)$ tai muita päihteitä $(78,8 \%)$. Ankkuritoiminnan kuvattiin kohdistuvan lähisuhde- ja perheväkivalta tilanteiden käsittelyyn $(63,8 \%)$, mutta osassa ankkureista tapausten käsittely oli ohjattu muille toimijoille. Ankkuritoiminnan kuvattiin myös kohdistuvan väkivaltaiseen radikalisoitumiseen liittyviin tilanteisiin ja vastaajista 55 prosenttia oli tunnistanut väkivaltaista radikalisoitumista ankkuritoiminnan asiakkailla. Lähes 28 prosenttia vastaajista ei kuitenkaan osannut sanoa oliko toimintaan osallistuvilla nuorilla ollut taustalla väkivaltaista radikalisoitumista. (Taulukko 2.)

Taulukko 2. Ammattilaisten ja esimiesten käsityksiä ankkuritoiminnan kohteista (\% ryhmän edustajista).

\begin{tabular}{lcccccc}
\hline \multirow{2}{*}{ Ankkuritoiminnan kohde } & \multicolumn{2}{c}{ kaikki } & \multicolumn{2}{c}{ ammattilaiset } & \multicolumn{2}{c}{ esimiehet } \\
& n & \% & n & \% & n & \% \\
\hline Tunnistettu rikos & 69 & 86,3 & 47 & 90,4 & 22 & 78,6 \\
Epäily rikoksesta & 67 & 83,8 & 48 & 92,3 & 19 & 67,9 \\
Huumeiden käyttö & 65 & 81,3 & 42 & 80,8 & 23 & 82,1 \\
Alkoholin ja tupakan käyttö & 63 & 78,8 & 42 & 80,8 & 21 & 75,0 \\
Riski väkivaltaiseen radikalisoitumiseen & 51 & 63,8 & 34 & 65,4 & 17 & 60,7 \\
Perheväkivaltatapaukset (perheessä lapsia) & 51 & 63,8 & 32 & 61,5 & 19 & 67,9 \\
Epäily väkivaltaisesta radikalisoitumisesta & 48 & 60,0 & 33 & 63,5 & 15 & 53,6 \\
Riski rikolliseen toimintaan & 44 & 55,0 & 44 & 84,6 & - & - \\
$\begin{array}{l}\text { Hyvinvointiin liittyvät ongelmat, jotka } \\
\text { tarvitsevat moniammatillista tukea }\end{array}$ & 39 & 48,8 & 28 & 53,8 & 11 & 39,3 \\
Väkivaltainen radikalisoituminen & 39 & 48,8 & 28 & 53,8 & 11 & 39,3 \\
$\begin{array}{l}\text { Lähisuhdeväkivaltatapaukset (perheessä } \\
\text { ei lapsia) }\end{array}$ & 34 & 42,5 & 23 & 44,2 & 9 & 32,1 \\
Terveyteen liittyvät ongelmat/tarpeet & 32 & 40,0 & 23 & 44,2 & 9 & 32,1 \\
\hline
\end{tabular}


Avoimissa kysymyksissä vastaajat täsmensivät sitä, miten ankkuritoiminnan kohteet ja asiakkaiden valinta vaihtelivat paikkakunnittain. Osassa paikkakunnista toiminnan ulkopuolelle rajattiin päihdekokeilut, koulukiusaaminen sekä näpistykset ja muut lievät rikostapaukset. Lisäksi osassa paikkakunnista toiminnan ulkopuolelle oli rajattu uusintarikokset, vakavat ja tutkintaa edellyttävät rikokset. Osa vastaajista kuvasi, että ankkuritoiminnan ulkopuolelle rajattiin ne nuoret, joita pidettiin niin sanottuina menetettyinä tapauksina. Tällaisina pidettiin nuoria, joiden ei koettu hyötyvän toiminnasta tai hänen tilanteeseensa oli yritetty jo aiemmin puuttua. Myös lähisuhde- ja perheväkivalta tilanteiden käsittely vaihteli: osassa paikkakunnista ne olivat ankkuritiimin tehtävänä, osassa ne ohjattiin muille viranomaisille. Vastaajat toivat myös esille, että ankkuritoimintaa tulisi jatkossa kehittää siten, että toiminnalla voitaisiin puuttua jo varhaisemmassa vaiheessa nuorten ongelmiin.

Laajan toimintakentän kuvattiin myös luovan uusia osaamistarpeita ammattilaisille, minkä vuoksi uusien tehtävien sisällyttämistä toimintaan tulisi vastaajien mukaan huolellisesti harkita. Esimerkkinä tuotiin esiin ekstresmismin vastainen työ. Sen koettiin poikkeavan merkittävästi perinteisestä nuorten kanssa tehtävästä työstä.

”Ankkuritoiminnan kautta pitäisi pyrkiä tavoittamaan entistä enemmän nuoria. Nyt ainakin meidän alueella ankkuritoiminnassa keskitytään paljon viharikoksiin, mikä osaltaan vie työpanosta muulta ehkäisevältä työltä.” (sosiaalitoimi: esimies)
"Ekstremismin osalta miettisin tarkoin kannattaako sitä edes yrittää sisällyttää ankkuritoimintaan. Omien kokemusteni mukaan henkilöt, jotka päätyönään työskentelevät lasten ja nuorten kanssa kokevat suurta epävarmuutta koko ekstremismi-kenttää kohtaan. Ankkurimainen työskentely (yhdessä tekeminen) ekstemismin parissa on hyvä toimintamalli, mutta sitä varten voisi rakentaa oman organisaationsa eikä yrittää sisällyttää sitä ankkurimalliin.” (poliisi: esimies)

Kyselyyn vastanneiden mukaan nuoret ohjautuivat ankkuritoimintaan yleisimmin rikosilmoitusten $(98,1 \%)$ tai muilta viranomaisilta tulleiden tietojen perusteella $(92,3 \%)$. Nuoren tarve ankkuritiimin monialaiseen tukeen oli tunnistettu myös ankkuritoiminnan kenttävalvonnan yhteydessä $(90,4 \%$ ) (esimerkiksi tiimin osallistuessa erilaisiin tapahtumiin) tai lastensuojeluilmoituksista $(88,5 \%$ ). (Taulukko 3.) Avointen vastausten perusteella nuoret ja aikuiset, joiden ankkuritoimintaan ohjautumisen syynä oli ollut epäily väkivaltaisesta radikalisoitumisesta, ohjautuivat toimintaan kouluilta, muilta viranomaisilta tai läheisiltä tulleiden tietojen perusteella.

Ammattilaiset ja esimiehet kokivat, että ankkuritoiminnalla pystytään estämään nuorten rikoskäyttäytymistä $(81,3 \%)$ ja lisäämään yhteiskunnallista sisäistä turvallisuutta $(80 \%)$. Lisäksi toiminnan koettiin edistävän nuorten terveyttä ja hyvinvointia (70 \%). Hieman alle puolet vastaajista $(43,8 \%)$ koki, että ankkuritoiminnalla pystytään myös ehkäisemään väkivaltaista radikalisoitumista. (Taulukko 4.)

Taulukko 3. Ammattilaisten käsityksiä ankkuritoimintaan ohjautumisesta (\% ammattilaisista).

\begin{tabular}{lcc}
\hline Ankkuritoimintaan ohjautuminen & $\mathbf{n}$ & $\mathbf{\%}$ \\
\hline Rikosilmoitus & 51 & 98,1 \\
Muut viranomaiset ilmoittavat & 48 & 92,3 \\
Tunnistetaan ankkuritoiminnan yhteydessä & 47 & 90,4 \\
Lastensuojeluilmoitus & 46 & 88,5 \\
Muut kollegat organisaation sisällä ilmoittavat (esim. toisesta yksiköstä) & 43 & 82,7 \\
Perheen jäsen tai joku muu läheinen ottaa yhteyttä & 36 & 69,2 \\
Muut toimijat ilmoittavat (esim. järjestötoimijat) & 35 & 67,3 \\
Asiakas ottaa itse yhteyttä & 33 & 63,5 \\
\hline
\end{tabular}


Taulukko 4. Vastaajien käsitykset ankkuritoiminnan tavoitteista, yhteistyön toteuttamisesta sekä lainsäädännöstä ja ohjauksesta (samaa mieltä \% vastaajista / ryhmä)

\begin{tabular}{|c|c|c|c|c|c|c|c|}
\hline & $\mathrm{Nt}$ & $\mathbf{P}$ & St & $\mathrm{Tt}$ & A & $\mathrm{E}$ & Kaikki \\
\hline \multicolumn{8}{|l|}{ Ankkuritoiminnalla pystytään... } \\
\hline ...estämään rikoskäyttäytymistä & 77,8 & 85,3 & 84,2 & 73,3 & 84,6 & 75,0 & 81,3 \\
\hline ...edistämään terveyttä ja hyvinvointia & 66,7 & 64,7 & 73,7 & 86,7 & 76,9 & 57,1 & 70,0 \\
\hline ...lisäämään sisäistä turvallisuutta & 77,8 & 85,3 & 78,9 & 66,7 & 86,5 & 67,9 & 80,0 \\
\hline ...estämään väkivaltaista radikalisoitumista & 33,3 & 35,3 & 47,4 & 53,3 & 42,3 & 46,4 & 43,8 \\
\hline \multicolumn{8}{|l|}{ Henkilöstö ja yhteistyö } \\
\hline Henkilöstö on sitoutunutta toimintaa & 77,8 & 70,6 & 89,5 & 86,7 & 78,4 & 82,1 & 78,8 \\
\hline Ankkuritoiminnan sisäinen tehtävänjako on selkeää & 66,7 & 64,7 & 73,7 & 53,3 & 67,3 & 53,6 & 62,5 \\
\hline Yhteistyö ankkuritiimin sisällä on sujuvaa & 77,8 & 73,5 & 84,2 & 53,3 & 73,1 & 67,9 & 71,3 \\
\hline $\begin{array}{l}\text { Yhteistyö ankkuritiimin ja esimiestason välillä on } \\
\text { sujuvaa }\end{array}$ & 44,4 & 52,9 & 63,2 & 26,7 & 36,5 & 67,9 & 47,5 \\
\hline $\begin{array}{l}\text { Yhteistyö ankkuritiimin ja muiden yhteistyötahojen } \\
\text { välillä on sujuvaa }\end{array}$ & - & 61,8 & 73,7 & 66,7 & 39,2 & 64,3 & 67,5 \\
\hline \multicolumn{8}{|l|}{ Lainsäädäntö ja ohjaus } \\
\hline $\begin{array}{l}\text { Laki ja säännökset tukevat ankkuritoiminnan } \\
\text { toteuttamista }\end{array}$ & 66,7 & 44,1 & 57,9 & 66,7 & 57,7 & 42,9 & 52,5 \\
\hline $\begin{array}{l}\text { Tunnen muiden toimintaan osallistuvien ammatti- } \\
\text { laisten lainsäädännön ja ohjauksen }\end{array}$ & 66,7 & 41,2 & 57,9 & 46,7 & 48,1 & 46,4 & 47,5 \\
\hline
\end{tabular}

$\mathrm{Nt}=$ nuorisotoimi, $\mathrm{P}=$ poliisi, $\mathrm{St}=$ sosiaalitoimi, $\mathrm{Tt}=$ terveystoimi, $\mathrm{A}=$ ammattilaiset, $\mathrm{E}=$ =simiehet

\section{MONIALAISEN YHTEISTYÖN TOTEUTTAMINEN JA KEHITTÄMINEN}

Vastaajat kokivat, että henkilöstö oli sitoutunutta ankkuritoimintaan $(78,8 \%)$ ja tiimin sisäinen tehtävän jako oli selkeää $(62,5 \%)$, vaikka vastaajat terveystoimesta olivat muita kriittisempiä $(53,3 \%)$. Yhteistyö ankkuritiimissä $(71,3 \%)$ sekä muiden yhteistyökumppaneiden kanssa $(67,5 \%)$ koettiin pääasiassa sujuvaksi. Vastaajista lähes puolet $(47,5 \%)$ koki yhteistyön tiimin ja esimiesten välillä toimivaksi. Terveystoimen vastaajista kuitenkin vain alle kolmasosa $(26,7 \%)$ oli samaa mieltä yhteistyön sujuvuudesta. Ammattilaisten ja esimiesten käsitykset tiimin ja esimiestason välisestä yhteistyöstä erosivat tilastollisesti merkitsevästi $(\mathrm{p}=0,002)$. Esimiesten käsitykset yhteistyöstä olivat positiivisempia, kuin ammattilaisten. (Taulukko 4.) Vastaajat kuvasivat, että yhteistyö perustuu tiimin ammattilaisten tasa-arvoon, osallisuuteen, sitoutumiseen ja luottamukseen.

Vastaajat toivat avoimissa kysymyksissä esiin tarpeen siitä, että yhteistyötä ankkuritiimin sisällä tulisi kehittää. Tähän keinoina esitettiin muun muassa säännölliset tiimipalaverit, tiedonvaihdon vahvistaminen sekä se, että huolehditaan ryhmäytymisestä ja ryhmädynamiikasta. Lisäksi ankkuritoimijoiden työnkuvia ja tiimin sisäisiä toimintatapoja tulisi selkeyttää. Vastaajat myös kokivat, että ankkuritoiminnassa työskentele- vien perehdytys ja lisäkoulutus eivät ole nykyisellään riittäviä. Koulutusta kaivattiin muun muassa lainsäädännöstä sekä väkivaltaisen radikalisoitumisen ennalta ehkäisemisestä. Vastaajien mukaan myös lisäkoulutus monialaisesta yhteistyöstä olisi tarpeen.

\footnotetext{
"Ryhmä vaatii jatkuvasti 'hoitoa' koska työ on raskasta ja asiakkaat usein melko vaikeita. Ryhmädynamiikka voi ajoittain olla hyvin haastavaa, koska samassa tiimissä työskentelee niin eri aloilta tulevia ihmisiä. Yhteiset kehittämiset ja työhyvinvoinnista huolehtiminen on elinehto ankkurin toiminnalle." (sosiaalityöntekijä)
}

Vastaajat toivat esille tarpeen kehittää yhteistyötä sidosryhmien ja yhteistyökumppaneiden kanssa, jotta nuorten tarpeisiin voitaisiin vastata aiempaa yksilöllisemmin. Keinoina esitettiin verkostoitumista muiden alueen toimijoiden ja erityisesti koulujen kanssa. Lisäksi toiminnasta tulisi tiedottaa aiempaa monipuolisemmin, jotta se olisi muille ammattilaisille tuttu. Toiminnan lähestyttävyyttä haluttiin myös kehittää ja tähän yhtenä keinona esitettiin uusien yhteydenottokanavien luomista yhteistyökumppaneille. Vastaajien mukaan yhteistyötä voitaisiin vahvistaa myös levittämällä tietoa 
ankkuritoiminnasta ja sen tarkoituksesta väestölle ja yhteistyökumppaneille, mutta myös toimintaan osallistuvien organisaatioiden sisällä.

"Enemmän yhteistyöpalavereita ja joka alueen ankkurille oma työnohjaus. Yhteisiä koulutuspäiviä, joissa voidaan yhdessä miettiä toiminnan eri osa-alueita ja kehittää niitä. Enemmän keskustelua ankkurilaisten kesken arjessa eri asiakastilanteista. Aidosti mietittäisiin yhdessä, mitä jollekin asiakastapaukselle kannattaisi tehdä. Toki tätä hankaloittaa tällä hetkellä se, että kaikilla on kiire, jolloin työn laatu yksittäisten asiakkaiden kohdalla voi jäädä joskus heikoksi.” (järjestötoimija)

Kyselyyn vastanneiden esimiesten mukaan päävastuu ankkuritoiminnan johtamisesta oli poliisilla $(64,3 \%)$. Sosiaalitoimella vastuu oli vain kolmasosalla paikkakunnista $(28,6 \%)$, ja hyvin harvoin terveystoimella $(7,1 \%)$ tai nuorisotoimella $(3,6 \%)$. Kaksi vastaajista $(7,1 \%)$ koki, että vastuuta ei ole kenelläkään ja 12 vastaajista $(42,9 \%)$ koki, että toimintaan ei ole nimetty koordinoivaa esimiestä. Vastaajat raportoivat, että esimies oli poliisista $(39,3 \%)$ tai sosiaalitoimesta (25\%). Ankkuritiimillä ei esimiesten $(43 \%)$ mukaan ollut nimetty päivittäistoiminnan johtajaa tai tiiminvetäjää. Niissä tiimeissä, joissa tiiminvetäjä oli, se oli yleensä poliisista $(25 \%)$, satunnaisesti sosiaalitoimesta $(14,3 \%)$ ja harvoin nuorisotoimesta $(3,6 \%)$.

Avoimissa kysymyksissä ammattilaiset toivat esille, että esimiehen keskeisenä tehtävänä oli tukea ja mahdollistaa monialaisen käytännön toteuttaminen. Tämä tarkoitti sitä, että esimiehen tuli linjata toiminta eli osoittaa ja vakiinnuttaa toiminnan yhteiset tavoitteet, kohteet ja työmenetelmät. Lisäksi esimiehen tehtävänä oli varmistaa se, että toiminnalla on riittävät taloudelliset resurssit ja toimivat työtilat ja -välineet. Esimiesten tuli myös vastata siitä, että monialaiseen työryhmään valitaan sopivat työntekijät ja heidät perehdytetään tehtäviin. Lisäksi esimiesten tuli varmistaa, että monialainen yhteistyö sujuu ja tiedonkulku toimii. Yhteistyön kannalta keskeistä oli, että esimerkiksi työvuorosuunnittelussa oli huomioitu eri toimijat. Esimiesten tuli toimia myös yhteyshenkilönä ankkuritiimin ja eri ammattiryhmien taustaorganisaatioiden välillä.
Ankkuritoimijoiden mukaan myös johtajien keskinäistä toimintaa tulisi kehittää. Esimiesten työskentely tulisi olla aiempaa paremmin koordinoitua ja heidän keskinäinen vastuunjakonsa selkeämpi. Vastaajien mukaan esimiesten välinen sujuva yhteistyö on tärkeää, jotta voidaan varmistaa se, että toimintaa ohjataan samaan suuntaan. Ankkuritoiminnalla tulisi vastaajien mukaan olla monitasoinen johtaminen: paikallinen ohjausryhmä, koordinoiva esimies sekä tiiminvetäjä tai ryhmänjohtaja. Toiminnan toteuttamisen keskeiseksi edellytykseksi sekä esimiehet että ammattilaiset kuvasivat esimiesten tuen. Kyselyyn vastaajien mukaan esimiesten tulisi olla sitoutuneita ja motivoituneita monialaiseen toimintaan ja sen kehittämiseen. Sitoutuminen tarkoitti työntekijöiden arvostusta sekä sitä, että esimiehet osallistuivat tiimin yhteisiin tapaamisiin. Esimiehillä tulisi vastaajien mukaan olla aikaa moniammatilliseen johtamiseen.

”Kaikkien esimiesten tulisi tietää mitä kaikkea kuuluu ankkuritoimintaan. Tehtävät ovat laajoja ja tuntuu, että oma esimies ei tiedä toiminnasta tarpeeksi eikä ole halukas ottamaan selvää. Tällöin oman lähiesimiehen tuki jää aika vähäiseksi.” (sosiaalityöntekijä)

"Jokaisen taustaorganisaation esimiehen tulisi olla hyvin perillä toiminnasta ja tukea alaisiaan. Pitäisi yhtä yhteistä vastuullista esimiestä kerrallaan koordinoimassa asioita hyvänä. Nyt tuntuu, ettei kukaan esimies ota mitään vastuuta mistään. Työntekijät ovat täysin oman onnensa nojassa jokainen. Vastauksia ja linjauksia myös vaikeaa saada, kun esimiehet eivät tee keskenään riittävän paljon yhteistyötä. Poliisin esimies vaihtunut jopa useita kertoja vuodessa [viransijaisuudet], joten ei tue ankkuritoimintaa lainkaan.” (sairaanhoitaja)

Kaikista vastaajista noin puolet $(52,5 \%)$ oli sitä mieltä, että nykyinen lainsäädäntö ja ohjaus tukevat ankkuritoiminnan toteuttamisen. Esimiehet olivat hieman kriittisempiä lainsäädäntöä ja ohjausta kohtaan, kuin ammattilaiset ja heistä 42,9 prosenttia oli sitä mieltä, että lainsäädäntö tukee toiminnan toteuttamista. Vastaajista puolet $(47,5 \%)$ koki tuntevansa muiden ankkuritoimin- 
taan osallistuvien ammattilaisten lainsäädännön ja ohjauksen. Poliisit olivat muita ammattiryhmiä kriittisempiä lainsäädännöstä ja sen tuntemisesta. Vastaajien käsitykset vaihtelivat kuitenkin toimialoittain. (Taulukko 4.)

Vastaajat totesivat tämänhetkisen lainsäädännön mahdollistavan erilaiset tulkinnat tiedonvaihdosta sekä muun muassa siitä, tarvitaanko nuoren suostumusta tiedonvaihtoon vai ei. Vastaajien mukaan nuorelta pyydetään suostumus ennen ankkuriprosessin aloittamista aina tai yleensä $(36,5 \%)$, mutta lähes yhtä moni $(38,5 \%)$ kertoi, että suostumusta ei pyydetä koskaan. Jos suostumusta ankkuritoimintaan ei saatu, nuori ohjattiin muille mahdollisille palvelutahoille tai kieltäytymisestä saattoi seurata myös lastensuojeluilmoitus.

Avoimissa kysymyksissä ankkuritoimijat toivat esille, että toimintaa kokonaisuudessaan tulisi yhtenäistää ja ankkuri tai sen kaltaiset toiminnot tulisi olla valtakunnallisesti nuorten saatavilla ja yhdenvertaisesti. Vastaajat pohtivat myös sitä, että toimintaa tulisi ohjata lainsäädännöllä ja kunnat tulisi velvoittaa toiminnan käynnistäminen jokaisella paikkakunnalla. Ohjauksen lisäksi tulisi myös varmistaa, että ankkuritoiminnalla on riittävät tilat ja henkilöstön toimintaedellytykset. Vastaajat totesivat, että ankkuritoimintaa toteutettiin paikkakuntakohtaisesti ja eroja todettiin olevan myös toimialojen sisällä. Lainsäädännön selkeyttäminen nähtiin yhdeksi keskeiseksi kehittämisen tarpeeksi erityisesti tiedonvaihtoon liittyen.

”Ankkuritoiminnan tulisi vahvemmin näkyä laissa ja esim. poliisilaitoksia tulisi vahvemmin velvoittaa toimintaan liittyen. Ajoittain on havaittavissa, että poliisia yritetään ottaa pois ankkuritoiminnasta tai sitä ei koeta tarpeellisena, mikä vesittää koko työskentelyn ajatuksen. Tällöin myöskään muiden ammattiryhmien organisaatiot eivät sitoudu toimintaan. Toiminnan tulisi korostua myös sosiaalipuolen uudistuksia mietittäessä, sillä mielestäni se korostuu merkittävänä asiana mm. perhe- ja lähisuhdeväkivaltatyön saralla.” (sosiaalityöntekijä)

\section{POHDINTA}

Suomalainen monialainen poliisin, sosiaalitoimen, terveystoimen ja nuorisotoimen yhteistyössä to- teutettu varhainen puuttuminen nuorten rikolliseen käyttäytymiseen ja hyvinvointiin liittyviin ongelmiin on laaja-alaista ja se vaihtelee paikkakunnittain. Toiminta kohdistuu ensi sijassa varhaiseen puuttumiseen nuoren rikoksiin ja niihin altistaviin riskeihin sekä päihteiden käyttöön. Alueellisesti on eroja siinä, käsittääkö toiminta myös lähisuhde- ja perheväkivaltaan liittyvät asiat. Ankkuritoimijoiden mukaan ensisijaiset toiminnan tavoitteet ovat yhteiskunnan sisäisen turvallisuuden edistäminen, nuorten rikosten estäminen sekä heidän terveytensä ja hyvinvointinsa edistäminen. Monialaisen yhteistyön vahvuuksia ovat henkilöstön sitoutuminen ja tiimin sisäinen tehtävänjako sekä yhteistyö niin tiimin sisällä kuin sidosryhmienkin kanssa. Yhteisissä käytännöissä ja ammattilaisten ja esimiesten osaamisessa todettiin kuitenkin olevan puutteita. Johtamisen todettiin olevan keskeinen osa monialaisen yhteistyön onnistumista. Sujuvan ja monialaisen tiedonvaihdon koettiin edellyttävän lainsäädännön ja valtakunnallisen ohjauksen täsmentämistä.

\section{NUORTEN TASA-ARVOINEN KOHTELU JA MONIALAISUUDEN VAHVISTAMINEN}

Nuorilla on julkisissa palveluissa oikeus tasaarvoiseen kohteluun, mutta ankkuritoiminta vaihtelee paikkakunnittain. Tasa-arvoinen kohtelu edellyttää sitä, että valtakunnallisessa toiminnassa on yhtenäiset käytänteet ja rakenteet, joita toteutetaan alueellisesti. Moniammatillinen yhteistyö vaatii selkeää alueellista ja kansallista koordinointia, jotta nuorille tarjottava tuki palveluiden kautta on kansallisesti yhdenvertaista sekä sisällön että saatavuuden suhteen (7). Yhdenmukaiset toimintatavat ja käsitteet voivat lisäksi tukea paikallisen, alueellisen ja valtakunnallisen tilannekuvan muodostamista nuorten tuen tarpeista, mitä tarvitaan varhaisen puuttumisen palveluiden suunnitteluun ja toteutukseen. Alueellisten erityispiirteiden huomioiminen monialaisia palveluita järjestettäessä edistää yhteistyön toteuttamista ja palveluiden kohdentamista alueen nuorten tarpeisiin. Kansallinen monialaisen yhteistyön koordinointi voi vaatia sekä alueellisen että kansallisen toiminnan organisoinnin selkeyttämistä, sillä byrokratia ja toimintamallien puute voi estää toiminnan toteuttamista (21). Tarkoituksenmukainen varhainen puuttuminen ja rikosten ennalta ehkäiseminen vaativat kuitenkin myös sen, että toiminnot mukautetaan nuoren yksilöllisiin 
tarpeisiin sekä suhteutetaan nuoren tekemään rikokseen tai hyvinvointiin liittyvään ongelmaan. Kaikille samanlaisen palvelun tarjoaminen on epätarkoituksenmukaista ja voi tuottaa enemmän haittaa kuin hyötyä (35).

Tämän tutkimuksen mukaan merkittävää vaihtelua oli siinä, miten, milloin ja mihin tarkoitukseen nuorelta pyydetään suostumus ennen toiminnan käynnistämistä. Vaihtelua voi osaltaan selittää ankkuritoiminnan organisointi paikallisesti. Tietyissä tilanteissa viranomaiset ovat kuitenkin usein velvoitettuja kysymään nuorelta suostumuksen (36-38). Samanaikaisesti monialaiseen toimintaan osallistuvat poliisit ja sosiaalitoimen ammattilaiset ovat velvoitettuja toimimaan ja vaihtamaan tietoa rikosten tai lastensuojeluun liittyvien tekijöiden nojalla myös ilman nuoren suostumusta. Kaikilla ammattilaisilla on myös lastensuojelulakiin pohjautuva velvollisuus ilmoittaa lastensuojelun tarpeesta sosiaalihuollon viranomaisille ja tietyistä rikosepäilyistä poliisille. (24-26.)

Suostumuksen pyytäminen nuorelta on keskeinen osa itsemääräämisoikeuden ja ihmisarvon kunnioittamista. Se on myös osa luottamuksen rakentamista ammattilaisten ja nuoren välillä ja voi siten osaltaan tukea nuoren kokemusta palveluiden merkityksellisyydestä. Nuoren suostumus kuvastaa hänen motivoitumista ja vastuun ottoa omasta tilanteestaan. Suostumus myös poistaa ammattilaisten tiedonvaihtoon liittyviä esteitä. Suostumuksen pyytäminen nuorelta voi vaatia viranomaisilta uutta osaamista ohjata ja tukea nuorta tilanteissa, joissa suostumuksen pyytäminen ei lainsäädännön perusteella olisi pakollista.

Osallistujien raportoiman suostumuksen monitulkintaisuuden mahdollistaa osaltaan nykyinen lainsäädäntö. Nykyinen ankkuritoimintaa ohjaava lainsäädäntö on toimialakohtaista eikä sitä ole laadittu monialaisen toiminnan toteuttamisen näkökulmasta $(36,37,39,40,42)$. Toimialakohtainen lainsäädäntö määrittää osaltaan ammattilaisten valtuuksia vaihtaa tietoa ja ne voivat vaihdella myös sen mukaan minkälaisesta asiakkuudesta on kyse. Nykyinen tietosuojalaki (43) koskee kaikkia ammattiryhmiä, mutta tämän tuntemus ja soveltaminen voi vielä olla puutteellista. Lainsäädännön pirstaleisuus voi osaltaan hankaloittaa esimerkiksi suostumuksen käytäntöjen kehittämistä ja kokonaiskuvan muodosta- mista (44). Kuten tutkimukseen osallistujat toivat esille, monialaisen toiminnan toteuttamista olisi syytä tukea lainsäädännöllä $(6,45,46)$, jotta monialaisen yhteistyön käytänteet ja esimerkiksi tiedonvaihdon toteuttaminen eri alojen välillä onnistuisi. Toisaalta ammattilaiset voivat tuntea heikosti lainsäädännön ja ohjauksen (6) ja siten sen tuntemisen vahvistaminen voisi osaltaan tukea monialaista tiedonvaihdon toteuttamista.

\section{MONIALAINEN YHTEISTYÖ NUORTEN HYVINVOINNIN EDISTÄMISESSÄ}

Tähän tutkimukseen osallistuneiden ammattilaisten mukaan varhaisen puuttumisen palveluilta vaaditaan kykyä reagoida ja mukautua muuttuviin yhteiskunnallisiin tilanteisiin sekä nuorten palveluntarpeisiin. Ankkuritoiminnassa tämä näkyy laajentuneina tehtävänkuvina siten, että väkivaltaisen radikalisoitumisen ehkäiseminen on sisällytetty toimintaan $(16,17)$. Laajentuvat tehtävänkuvat ja nuorten tarpeisiin vastaaminen vaativat palveluiden jatkuvaa kehittämistä sekä ammattilaisten osaamisen ajantasaisuudesta huolehtimista.

Tutkimuksen osallistujien mukaan yhteistyö ammattilaisten välillä on pääosin sujuvaa, vaikka myös kehittämistarpeita tuotiin esiin. Ammattilaisten välisen tehtävänjaon ja toisten ammattiryhmien roolien tunteminen (6) voisi edelleen vahvistaa yhteistyön toteuttamista ja yhteisten tavoitteiden saavuttamista. Tutkimuksen tulokset viittaavat siihen, että eri ammattiryhmillä voi kuitenkin olla eroavat käsitykset toiminnasta. Tämä voi osaltaan selittyä ammattilaisten erilaisilla perustehtävillä ja orientaatioperustoilla. Koska tämän tutkimuksen otos oli rajallinen, eri ammattiryhmien käsitysten eroja on jatkossa syytä edelleen selvittää.

Sekä ammattilaisten että esimiesten mukaan monialaisen yhteistyön toteuttaminen vaatii esimiesten ja organisaatioiden tukea. Tämä on todettu myös aikaisemmissa julkaisuissa (7,21, 45,47). Ankkuritoiminnan erityispiirteenä on se, että toiminta vaatii monialaista johtamista ja ammattilaiset edustavat eri julkisia toimialoja. Esimiehiltä odotetaan osaamista moniammatilliseen johtamiseen, sekä taitoa toteuttaa sitä yhteistyössä eri alojen esimiesten kanssa. Tämä vaatii esimiehiltä laaja-alaista osaamista ja taitoja mahdollistaa ja ylläpitää ammattilaisten yhteistyötä ja yhteenkuuluvuutta. Monialaisessa 
johtamisessa korostuu innovatiivisuus, vuorovaikutustaidot sekä johtamisen selkeys $(7,48)$. Jatkossa tulisi selvittää millaisena monialaisen toiminnan johtajat kokevat oman osaamisensa suhteessa johdettavien käsityksiin sekä miten esimiesten osaamisen kehittymistä voitaisiin tukea.

Tutkimustulosten perusteella ankkuritoiminta on työkalu monialaisen yhteistyön toteuttamiseen, ja ammattilaiset kokevat yhteistyön toimivaksi ja tehokkaaksi tavaksi edistää nuorten hyvinvointia ja ehkäistä rikoksia. Tämä on yhdenmukaista aiempien vastaavien moniammatillisten tutkimusten kanssa (21). Monialaisen yhteistyön vaikuttavuuden osoittaminen nuorten hyvinvoinnin edistämisessä on kuitenkin muun ennaltaehkäisevän työn tavoin vaativa ja osin mahdoton osoittaa. Jatkossa tätä olisi kuitenkin syytä tutkia, jotta saataisiin esille varhaisen puuttumisen lyhyen ja pitkän aikavälin seuraukset niin yksittäisille nuorille kuin heidän perheilleen ja koko väestölle. Myös toiminnan taloudellisiin kustannuksiin (35) tulisi kohdistaa aiempaa enemmän tutkimusta.

\section{LUOTETTAVUUS JA TUTKIMUSETIIKKA}

Tutkimuksen luotettavuuskysymykset kohdistuvat aikaisempaan kirjallisuuteen ja aineiston keruuseen. Aikaisempi kirjallisuus haettiin kotimaisista ja kansainvälisistä tietokannoista käyttämällä monialaista yhteistyötä kuvaavia hakusanoja ja niiden yhdistelmiä. Koska monialaisen yhteistyön käsitteistö on monitieteistä, laaja-alaista ja osin vakiintumatonta, on riski, että hakujen systemaattisuudesta huolimatta joitain aiheen kannalta relevantteja lähteitä on jäänyt huomiotta.

Tutkimusta varten laadittiin kyselylomake yhteistyössä eri alojen asiantuntijoiden sekä ankkurissa työskentelevien ammattilaisten kanssa. Tällä pyrittiin vahvistamaan lomakkeen validiteettia ja varmistamaan, että kysely kattaa kaikki toiminnan kannalta keskeiset tekijät ja on vastaajalle ymmärrettävä ja helposti täytettävä (49). Tutkimukseen rekrytoitiin kaikki ankkuritoiminnan ammattilaiset, mutta eri alojen ammattilaisten määrä oli suhteellisen pieni. Analyysin luotettavuuden vuoksi tutkimuksessa ei vertailtu eri ankkuripaikkakuntien tuloksia keskenään. Valtaosa tutkimukseen osallistuneista oli alle 50-vuotiaita naisia, mikä on syytä huomioida tutkimuksen tuloksia tulkittaessa. Pääosa vastaajista oli poliisista, mikä on voinut osaltaan myös vinouttaa tuloksia. Tutkimuksen vastausprosentti oli 41, joten tulokset heijastavat monialaiseen toimintaan osallistuvien ammattilaisten käsityksiä, mutta ne rajautuvat ankkuritoiminnan toteuttamiseen. Lisäksi on huomionarvoista se, että ankkuritoimintaa toteutetaan paikallisesti sovitetuilla tavoilla, mikä on voinut vaikuttaa vastaajien käsityksiin toiminnasta ja sen sisällöistä. Tutkimuksen tulosten tulkintaa käsiteltiin yhteistyössä eri alojen asiantuntijoiden sekä ankkuritoiminnan edustajan kanssa, mutta tulosten tulkinta laajemman vastaajajoukon kanssa olisi voinut vahvistaa tulosten merkityksen ymmärtämistä.

Tutkimuksen kaikissa vaiheissa noudatettiin tutkimusetiikkaa (50) sekä vastuullisia tutkimuskäytäntöjä (51). Tutkimukselle haettiin ja saatiin osallistuvista organisaatioista tutkimusluvat. Kaikki osallistujat antoivat tietoon perustuvan suostumuksen ennen sähköiseen kyselyyn vastaamista. Vastaajilla oli myös mahdollisuus esittää tutkimuksesta kysymyksiä tutkijoille joko puhelimitse, sähköpostitse tai tiedotustilaisuudessa.

\section{JOHTOРÄÄTÖKSET}

Monialainen yhteistyö poliisin, sosiaalitoimen, terveystoimen ja nuorisotoimen välillä, nuorten rikoksiin ja hyvinvointiin liittyviin ongelmiin puuttumisessa vaihtelee paikkakunnittain. Tämä yhtäältä vastaa alueellisesti nuorten erilaisiin tarpeisiin mutta toisaalta voi vaarantaa nuorten yhdenvertaisen palveluiden saatavuuden. Toiminnalla pyritään edistämään yhteiskunnan sisäistä turvallisuutta ja nuorten hyvinvointia. Tämä edellyttää monialaisen toiminnan ammattilaisilta ja esimiehiltä laaja-alaista osaamista vastata nuorten ja yhteiskunnan muuttuviin tarpeisiin, mutta myös toiminnan jatkuvaa kriittistä arviointia ja kehittämistä. Kansallisesti monialaisen yhteistyön koordinointi ja lainsäädännön selkeyttäminen voivat tukea toiminnan toteuttamisessa erityisesti tiedonvaihdon osalta. Jatkossa monialaisen yhteistyön kriittinen tarkasteleminen ja tutkimuksellisen perustan vahvistaminen on edelleen tarpeen.

\section{RAHOITTAJAT:}

Tutkimusta ovat rahoittaneet Euroopan Sisäisen turvallisuuden rahasto, Sisäministeriö ja Poliisihallitus. 
KIRJOITTAJIEN KONTRIBUUTIOT:

Moilanen, Airaksinen ja Kangasniemi osallistuivat tutkimuksen suunnitteluun ja käsikirjoituksen kirjoittamiseen. Moilanen ja Airaksinen toteutti- vat aineiston keruun. Moilanen ja Kangasniemi analysoivat aineiston. Kaikki kirjoittajat osallistuivat käsikirjoituksen kommentointiin.

Moilanen, T., Airaksinen, M., Kangasniemi, M. Early intervention in adolescents' crimes and wellbeing-related problems: survey for professionals engaged in multiprofessional collaboration. Sosiaalilääketieteellinen aikakauslehti - Journal of Social Medicine 202 I: 58: 3-I 5.

The purpose of this study was to describe the perceptions of police, social-, health- and youth sector professionals that engage in multiprofessional collaboration, on early intervention in adolescents' wellbeing problems and criminal behavior. The aim was to describe professionals' perceptions of the development of the activities. The data were collected using an electronic survey from professionals $(\mathrm{n}=52)$ and their supervisors $(\mathrm{n}=28)$ working in multiprofessional anchor teams in spring 2018. The data were analyzed with descriptive statistics. Based on the results, multiprofessional collaboration had been carried out when an adolescent had committed a crime $(86 \%)$, was suspected of a crime $(84 \%)$ or had used drugs $(81 \%)$ or other intoxicants $(79 \%)$. Over half of the respondents $(55 \%)$ had recognized violent radicalization among their clients. The respondents felt that using the anchor activities can prevent juvenile delinquency $(89 \%)$, in- crease internal security in society $(81 \%)$ and promote health and wellbeing $(70 \%)$. The strengths of collaboration included employee commitment $(79 \%)$ and collaboration within the team and with partners. However, the professionals noted that there was need for further development in the collaboration and related leadership. More precise legislation concerning topics such as information sharing would also support multiprofessional collaboration. In the future, more knowledge is needed about how to manage multiprofessional activities in a multidisciplinary manner and secure adolescents' equal access to the services through cohesive national steering.

Keywords: adolescents, early intervention, survey, wellbeing

$\begin{array}{cc}\text { Saapunut } & 10.12 .2019 \\ \text { Hyväksytty } & 11.08 .2020\end{array}$

\section{LÄHTEET}

(1) Elbogen EB, Johnson SC. The intricate link between violence and mental disorder. Arch Gen Psychiatry 2009;66:152-161. https://doi.org/10.1001/ archgenpsychiatry.2008.537.

(2) Lorenc T, Clayton S, Neary D, ym. Crime, fear of crime, environment, and mental health and wellbeing: mapping review of theories and causal pathways. Heal Place 2012;18:757-765. https://doi.org/10.1016/j. healthplace.2012.04.001.

(3) Shadowen NL, Guerra NG, Reyes Rodas G, $y m$. Community readiness for youth violence prevention: a comparative study in the US and Bolivia. Vulnerable Child Youth Stud 2017;12:117-129. https://doi.org/10.1080/17450128.2017.12864 23.

(4) Howe RB. Children's rights as crime prevention. Int J Child Rights 2008;16:457-474. https://doi.org/10.1163/157181808X303519.

(5) Pabayo R, Dunn EC, Gilman SE, ym. Income inequality within urban settings and depressive

(6) Leppäkoski T, Koivuluoma M, Perälä S, ym. Moniammatillisen yhteistyön muutokset ja kehittämistarpeet lasten ja nuorten auttamisessa. Yhteiskuntapolitiikka 2017;82:200-211.

(7) Perälä M-L, Halme N, Nykänen S. Lasten, nuorten ja perheiden palveluja yhteensovittava johtaminen. Terveyden ja hyvinvoinnin laitos, 19; 2012. Luettu 18.6.2019. http://urn.fi/URN:ISBN:978-952-245-529-1

(8) Kuikka M. Mitä varhaisella puuttumisella tarkoitetaan? 2005. Teoksessa: Varpu. Lapselle tukea ajoissa. Luettu 9.6.2020.

https://www.lskl.fi/materiaali/lastensuojelunkeskusliitto/Varpu-tukea-lapselle-ajoissa.pdf

(9) WHO. Human resources for health framework for action on interprofessional education $\&$ collaborative practice 2010:1-64. https://doi.org/10.1128/JVI.76.8.4044.

(10) Karam M, Brault I, Van Durme T, ym. Comparing interprofessional and inter- 
organizational collaboration in healthcare: a systematic review of the qualitative research. Int J Nurs Stud 2018;79:70-83. https://doi.org/10.1016/j.ijnurstu.2017.11.002.

(11) Sloper P. Facilitators and barriers for cooridnated multi-agency services. Child Care, Heal Dev 2004;30:571-580. https:doi.org/10.1111/j.13652214.2004.00468.x

(12) Petri L. Concept analysis of interdisciplinary collaboration. Nurs Forum 2010;45:73-82. https://doi.org/doi: 10.1111/j.17446198.2010.00167.x.

(13) Harris A, Allen T. Young people's views of multiagency working. Br Educ Res J 2011;37:405419. https://doi.org/10.1080/01411921003692876.

(14) Moran P, Jacobs C, Bunn A, ym. Multi-agency working: implications for an early-intervention social work team. Child Fam Soc Work 2007;12:143-151. https://doi.org/10.1111/j.13652206.2006.00452.x.

(15) Moilanen T, Airaksinen M, Kangasniemi M. Ankkuritoiminnan käsikirja. Moniammatillinen yhteistyö nuorten hyvinvoinnin edistämiseen ja rikosten ennaltaehkäisemiseen. Sisäministeriön julkaisu 16/2019. Luettu 18.6.2019. http://urn.fi/ URN:ISBN\%20978-952-324-256-2

(16) Sisäministeriö. Kansallinen väkivaltaisen radikalisoitumisen ja ekstremismin ennalta ehkäisyn toimenpideohjelma. Sisäministeriön julkaisu 15/2016. Luettu 18.6.2019. http://urn.fi/ URN:ISBN:978-952-324-092-6

(17) Sisäministeriö. Vahvemmat yhdessä. Sisäministeriön julkaisu 31/2014. Luettu 18.6.2019. http://urn.fi/URN:ISBN:978-952-491-999-9

(18) Sisäministeriö. Ankkuritoiminta alueittain 2019. Luettu 18.6.2019. https://ankkuritoiminta.fi/ ankkuritoiminta-eri-poliisilaitoksilla

(19) Hardin L, Kilian A, Spykerman K. Competing health care systems and complex patients: an inter-professional collaboration to improve outcomes and reduce health care costs. J Interprofessional Educ Pract 2017;7:5-10. https://doi.org/10.1016/j.xjep.2017.01.002.

(20) Sugimoto-Matsuda J, Braun K. The role of collaboration in facilitating policy change in youth violence prevention: a review of the literature. Prev Sci 2014;15:194-204. https://doi.org/10.1007/s11121-013-0369-7.The.

(21) Cooper M, Evans Y, Pybis J. Interagency collaboration in children and young people's mental health: a systematic review of outcomes, facilitating factors and inhibiting factors. Child Care Health Dev 2016;42:325-342. https://doi.org/10.1111/cch.12322.

(22) Hietamäki J, Kuusinen V, Pursi K, ym. Lastensuojeluilmoitusprosessi moniammatillisen yhteistyön näkökulmasta. Yhteiskuntapolitiikka 2017;82:417-29.
(23) Callaghan J, Pace F, Young B, ym. Primary mental health workers within youth offending teams: a new service model. J Adolesc 2003;26:185-199. https://doi.org/10.1016/S0140-1971(02)00131-8.

(24) Kaehne A. Multi-agency protocols as a mechanism to improve partnerships in public services. Local Gov Stud 2015;41:321-338. https://doi.org/10.1080/03003930.2013.861819.

(25) Spitzer W, Silverman E, Allen K. From organizational awareness to organizational competency in health care social work: the importance of formulating a 'professionin-environment' fit. Soc Work Health Care 2015;54:193-211. https://doi.org/10.1080/00981389.2014.990131.

(26) Arnkil E. Sosiaalityön rajasysteemit ja kehitysvyöhyke. Väitöskirja. Jyväskylän yliopisto; 1992.

(27) Inkilä J, Helminen M, Aalto P, ym. Moniammatillinen yhteistyö perheen kanssa lasten kaltoinkohtelutilanteissa. Hoitotiede 2016;28:204-216.

(28) Veijola A, Isola A, Taanila A. Moniammatillinen perhetyö edellyttää keskustelua. Sos Lääketiet Aikak 2006;43:186-197.

(29) Vierula T, Pösö T, Paavilainen E. Moniammatillisuus ja palvelutarvearviointi lapsija perhepalveluissa. Ammattilaisten näkemykset pulmakohdista. Yhteiskuntapolitiikka 2019;84:292-300.

(30) Rautio S. Kumppanuus ja moniammatillinen yhteistyö neuvolan perhetyössä. Sos Lääketiet Aikak 2014;51:191-202.

(31) Collin K, Valleala UM, Herranen S, ym. Moniammatillisen yhteistyön muodot ja haasteet päivystystyön hoitoprosessissa. Sos Lääketiet Aikak 2012;49:31-43.

(32) Saikku P. Hallinnan rajoilla. Monialainen koordinaatio vaikeasti työllistyvien työllistymisen edistämisessä. Väitöskirja. Helsingin Yliopisto: Helsingin yliopisto; 2018.

(33) Saikku P, Rajavaara M. Monialainen yhteistyö paikallisessa työllisyyden hallinnassa. Integroiva kirjallisuuskatsaus. Sosiaali- ja terveysturvan raportteja. Kela; 2017. Luettu 9.6.2020. http://hdl.handle.net/10138/229018

(34) Vanhanen S. Monialainen yhteistyö asiantuntijuuden muokkaajana kotouttamistyössä näkökulmana poliisin työ. Yhteiskuntapolitiikka 2020;85:31-41.

(35) Burssens D. Evaluation of crime prevention: escaping the tunnel vision on effectiveness. Howard J Crime Justice 2016;55:238-254. https://doi.org/10.1111/hojo.12155.

(36) Nuorisolaki 21.12.2016/1285. https://www.finlex.fi/fi/laki/jantasa/2016/ 20161285 ? search \% 5Btype \% 5D=pika\&search\% 5 Bpika \%5D=nuorisolaki. 
(37) Laki potilaan asemasta ja oikeuksista 17.8.1992/785.

https://www.finlex.fi/fi/laki/ajantasa/ 1992/19920785?search\%5Btype\%5D $=$ pika\&search $\% 5$ Bpika $\% 5 \mathrm{D}=$ laki potilaan asemasta ja oikeuksista.

(38) THL. Luo luottamusta, suojele lasta. Opas yhteistyöstä lapsia ja perheitä työssään kohtaaville. Terveyden ja hyvinvoinnin laitos; 2016. Luettu 18.6.2019. http://urn.fi/URN:ISBN:978-952-302-642-1

(39) Poliisilaki 22.7.2011/872. https://www.finlex.fi/fi/laki/ajantasa/ 2011/20110872?search\%5 Btype \%5D= pika\&search\%5Bpika\%5D= poliisilaki.

(40) Lastensuojelulaki 13.4.2007/417. https://www.finlex.fi/fi/laki/ajantasa/2007/ 20070417? search\%5Btype \% 5D=pika\& search \%5Bpika\%5D=lastensuojelulaki.

(41) Rikoslaki 19.12.1889/39. https://www.finlex.fi/fi/laki/ ajantasa/1889/ 18890039001?search\% 5Btype \%5D=pika\&search\%5Bpika\%5D $=$ rikoslaki.

(42) Laki sosiaalihuollon asiakkaan asemasta ja oikeuksista 22.9.2000/812.

https:/www.finlex.fi/fi/laki/ajantasa/2000/ 20000812? search\%5Btype \%5D

=pika \&search $\% 5$ Bpika $\% 5 \mathrm{D}=$ laki sosiaalihuollon asiakkaan.

(43) Tietosuojalaki 5.12.2018/1050. https://www.finlex.fi/fi/laki/ ajantasa/2018/20181050?search $\% 5$ Btype $\% 5 \mathrm{D}=$ pika\&search \%5Bpika \% 5D=tietosuojalaki.

(44) Lennox C, Mason J, Mcdonnell S, ym. Information sharing between the national health service and criminal justice system in the United Kingdom. J Forensic Nurs 2012;8:131-137. https://doi.org/10.1111/j.1939 3938.2012.01138.x.

(45) Palinkas LA, Fuentes D, Finno M, ym. Inter-organizational collaboration in the implementation of evidence-based practices among public agencies serving abused and neglected youth. Adm Policy Ment Heal Ment Heal Serv Res 2014;41:74-85.

https://doi.org/10.1007/s10488-012-0437-5.

(46) Gil-Garcia JR, Sayogo DS. Government interorganizational information sharing initiatives: understanding the main determinants of success. Gov Inf Q 2016;33:572-582. https://doi.org/10.1016/j.giq.2016.01.006.

(47) Vestergaard E, Nørgaard B. Interprofessional collaboration: an exploration of possible prerequisites for successful implementation. J Interprof Care 2018;32:185-195. https://doi.org/10.1080/13561820.2017.13637 25 .

(48) Smith T, Fowler-Davis S, Nancarrow S, ym. Leadership in interprofessional health and social care teams: a literature review. Leadersh Heal Serv 2018;31:452-467. https://doi.org/10.1108/LHS-06-2016-0026.

(49) DeVellis R. Scale development. Theory and applications. 4th ed. Los Angeles: SAGE; 2017.

(50) World Medical Association. World medical association declaration of Helsinki: ethical principles for medical research involving human subjects. Clin Rev 2013;310:2191-2194.

(51) TENK. Ihmiseen kohdistuvan tutkimuksen eettiset periaatteet ja ihmistieteiden eettinen ennakkoarviointi Suomessa. Helsinki: Tutkimuseettisen neuvottelukunnan julkaisuja 3/2019.

\section{Tanja Mollanen}

TtT, Erikoistutkija, post doc-tutkija

Turun yliopisto, Hoitotieteen laitos

\section{Matti Airaksinen \\ HTM, Rikoskomisario \\ Lounais-Suomen poliisilaitos}

Mari Kangasniemi

TtT, dosentti, yliopistotutkija

Turun yliopisto, Hoitotieteen laitos 